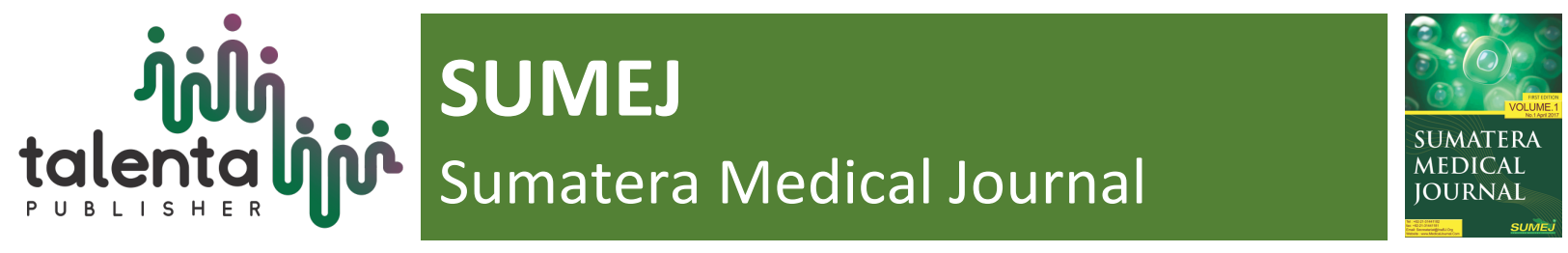

\title{
The effect of Ethanol Extract of Grape (Vitis vinifera) as an Anti-Aging for Women in Productive Age
}

Siti Nadhila ${ }^{*}$, Tri Widyawati ${ }^{2}$

${ }^{1}$ Faculty of Medicine, Universitas Sumatera Utara, Medan, North Sumatera, Indonesia ${ }^{2}$ Department of Pharmacology, Faculty of Medicine, Universitas Sumatera Utara, Medan, North Sumatera, Indonesia

\begin{abstract}
The aging process occurs in all parts of the body including the face. One of the factors that can influence this process is free radicals which can be suppressed by antioxidants. Grapes (Vitis vinifera) are known to contain high antioxidant compounds. This research was conducted to determine the anti-aging activity of grape ethanol extract ( $V$. vinifera) in clay mask preparations. Grape ethanol extract obtained by maceration and formulated in clay mask dosage form with 4 concentrations namely FI (2.5\%), FII (5\%), FIII (7.5\%) and F0 as a control. A total of 12 volunteers who met the inclusion criteria were applied to the mask every week for 4 weeks and evaluated the water content, smoothness, large pores, many blemishes and facial skin wrinkles before and after application in each treatment. Mask stability was evaluated for 12 weeks at room temperature. Data were analyzed by the Kruskal Wallis and Friedman tests. After 4 weeks of treatment, the highest changes including humidity (12.63\%), pore size (50\%), blemishes (57.32\%) and wrinkles (75.69\%) were found in FIII. While changes in skin smoothness were found in FII by $34.04 \%$. There was a significant moisture difference between F0-FIII $(p<0.05)$, a significant difference in evenness between F0-FI, F0-FII and F0-FIII ( $p<0.05)$, a significant difference in spots between F0-FIII $(p<0.05)$ and significant differences in wrinkles between F0-FIII $(p<0.05)$. Grape ethanol extract in clay mask preparations has anti-aging activity.
\end{abstract}

Keywords: Anti-aging, Ethanol extract, Grapes (Vitis vinifera), Clay Mask

\section{Introduction}

The aging process is an inevitable physiological process that will be experienced by every human being. This process is irreversible which covers all organs of the body including the skin. The aging process is divided into 2 , first, the intrinsic process, which is a physiological aging process that takes place naturally, due to various factors from within the body itself such as genetics, chronic diseases and hormones. Second, the extrinsic aging process is due to being influenced by external factors such as exposure to excessive sunlight, pollution, smoking habits, rarely consuming vitamins, unbalanced nutrition $[1,2,3]$.

\footnotetext{
*Corresponding author at: Faculty of Medicine, Universitas Sumatera Utara, Medan, Indonesia]

E-mail address: sitinadhila06@gmail..com
} 
Environmental factors such as pollution, excessive ultraviolet (UV) intensity, temperature, chemicals, and nutritional deficiencies can result in the human body being exposed to free radicals. Free radicals are molecules that have one or more unpaired electrons or free electrons in their outer orbits which are unstable. This molecule is very reactive looking for its electron pairs in an effort to achieve stability so it is also called Reactive Oxygen Species (ROS). If free radicals are excessive, will create an imbalance between free radical molecules and endogenous antioxidants. The amount of free radicals that exceeds the body's capacity to neutralize them, oxidative stress will be formed which can cause damage to the structure of cells, tissues and organs. [4,5].

In the medical field, it is known that free radicals are the cause of various pathological conditions such as liver disease, coronary heart disease, cancer, diabetes, cataracts, liver disease, and various early aging processes [6].

Free radical activity can be suppressed with antioxidants. Antioxidants are molecules that can donate electrons to free radical molecules, so they can stop the chain reaction [7].

Based on the development of human civilization in modern times, found several instant methods used by women as skin aging, for example by using cosmetic surgery to tighten wrinkles, with laser technology to remove wrinkles, and in the most believed effective ways to ward off premature aging by relying on antioxidants that are sourced from foods and drinks derived from plants. This last method can be believed to provide more natural benefits to the skin, safer and relatively inexpensive [8].

Many plants that have antioxidant properties are plants that contain carotenoids and polyphenols, especially flavonoids so that many are formulated as natural antioxidants that can be made in oral dosage forms as vitamins and topically as skin care products or cosmetics [9].

The formulation for making natural face masks needs to be done as an alternative choice. Face masks can be made from natural ingredients that are formulated into making natural face masks that are useful for reducing wrinkles and blemishes on the face [10].

Grapes (Vitis vinifera) are rich in phytochemical resveratrol polyphenol compounds [11]. Resveratrol is a powerful antioxidant. Besides resveratrol there are other antioxidants in wine, namely anthocyanin. Anthocyanins include antioxidant polyphenol groups which are also beneficial for anti-allergic, anti-inflammatory, anti-microbial and anti-cancer properties [12]. Grape seed extract is also known to have powerful antioxidant properties, especially the content of proanthocyanidins which have greater antioxidant strength compared to other antioxidants such as 
vitamin $\mathrm{C}$, vitamin $\mathrm{E}$ and $\beta$-carotene in protecting cells from DNA damage and lipid peroxidation due to free radical chain reactions [13].

\section{Method}

This study is more specific as a pilot study, with small sample and short duration on the study. The mask was made by extracting grapes first. Then after extraction, the active ingredients in the grapes (the extract of the grapes) will be mixed in a clay mask made from Bentonite, Kaolin, Sodium Metabisulfite, Nipagin, Glycerin, Xanthan Gum, Titanium Dioxide, and Sodium Lauryl

Sulfate [14]. There are 4 groups of treatment. Group 1 (F0) is the clay mask with zero extract of

\begin{tabular}{cccccccccc}
\hline & \multicolumn{2}{c}{ Week 1 } & \multicolumn{2}{c}{ Week 2 } & \multicolumn{2}{c}{ Week 3 } & \multicolumn{2}{c}{ Week 4 } & p \\
\cline { 2 - 9 } Formula & \multirow{2}{*}{ Before } & \multirow{2}{*}{ After } & Before & After & Before & After & Before & After & (Friedman) \\
\hline F0 & $30,33 \pm 0,57$ & $31,33 \pm 0,57$ & $31,00 \pm 1,00$ & $32,00 \pm 1,00$ & $31,66 \pm 0,57$ & $32,33 \pm 0,57$ & $32,00 \pm 0,00$ & $32,66 \pm 0,57$ & 0,01 \\
\hline FI & $30,00 \pm 0$ & $31,66 \pm 0,57$ & $30,00 \pm 0,00$ & $31,66 \pm 0,57$ & $31,00 \pm 0,00$ & $32,33 \pm 0,57$ & $32,00 \pm 1,00$ & $33,00 \pm 1,00$ & 0,01 \\
\hline FII & $30,33 \pm 0,57$ & $32,66 \pm 0,57$ & $30,33 \pm 0,57$ & $32,33 \pm 0,57$ & $30,66 \pm 0,57$ & $32,66 \pm 0,57$ & $31,33 \pm 0,57$ & $33,66 \pm 0,57$ & 0,01 \\
\hline FIII & $31,66 \pm 0,57$ & $32,66 \pm 1,15$ & $30,66 \pm 1,15$ & $32,66 \pm 0,57$ & $31,66 \pm 0,57$ & $33,33 \pm 0,57$ & $33,00 \pm 1,00$ & $35,66 \pm 0,57$ & 0,01
\end{tabular}

$\mathrm{p}$

(Kruskal

Wallis)

0,06

0,12

0,43

0,35

0,11

0,21

0,16

0,05

ethanol extract of grape, group 2 (FI) is the clay mask with 2,5\% ethanol extract of grape, group 3 (FII) is the clay mask with 5\% ethanol extract of grape and group 4 (FIII) is the clay mask with $7,5 \%$ ethanol extract of grape. Every group receive the same treatment within 4 weeks of treatment. This is a research to determine which concentration between F0, FI, FII and FIII has the best effect for improvement in moisture and evenness, reduced pore, spot and wrinkle. This research was conducted by direct application of the mask to the face and will be tested with skin analyzer (Aramo - SG) before and after the application of the clay mask. This research take place in Cosmetology Laboratory, Faculty of Pharmacy, University of Sumatera Utara.

The sample of this study was 12 women who had characteristics according to the inclusion criteria: Women, productive age 20-25 years, no history of illness related to allergies, willing to participate in the study and signing the informed consent. Exclusion Criteria: Women with history of allergies and using anti-aging treatment care. Drop-out criteria: Allergic reaction appeared during the experiment test and using anti-aging treatment care during experiment test.

\section{Result}


This study was conducted on 12 women who met the inclusion criteria by using sample calculation for hypothesis testing in continuous data with Malondialdehid (MDA) value potential ergogenic of grapes [15]. The skin will be tested with skin analyzer before and after using the mask once a week. The mask should be used $1-2$ times a week .

Table 1. Result of moisture (Mean $\pm \mathrm{SD})$ in research subject

Table 1 shows change in the moisture / moisture content on the skin of volunteers after wearing a clay mask. These changes can be seen from the increased water content on facial skin in each formula (F0, FI, FII, FIII).

Table 2. Result of evenness (Mean $\pm \mathrm{SD}$ ) in research subject

\begin{tabular}{|c|c|c|c|c|c|c|c|c|c|}
\hline \multirow[b]{2}{*}{ Formula } & \multicolumn{2}{|c|}{ Week 1} & \multicolumn{2}{|c|}{ Week 2} & \multicolumn{2}{|c|}{ Week 3} & \multicolumn{2}{|c|}{ Week 4} & \multirow{2}{*}{$\begin{array}{c}\mathrm{p} \\
\text { (Friedman) }\end{array}$} \\
\hline & Before & After & Before & After & Before & After & Before & After & \\
\hline F0 & $39,66 \pm 1,52$ & $35,33 \pm 4,50$ & $39,66 \pm 1,52$ & $36,66 \pm 2,08$ & $35,66 \pm 2,30$ & $31,33 \pm 1,52$ & $36,33 \pm 2,08$ & $28,66 \pm 2,51$ & 0,01 \\
\hline FI & $41,66 \pm 2,08$ & $38,66 \pm 1,15$ & $40,33 \pm 1,15$ & $33,66 \pm 1,15$ & $38,66 \pm 1,52$ & $34,33 \pm 0,57$ & $36,66 \pm 2,51$ & $32,00 \pm 3,60$ & 0,00 \\
\hline FII & $47,00 \pm 1,00$ & $39,66 \pm 1,15$ & $43,66 \pm 2,08$ & $37,00 \pm 2,00$ & $42,66 \pm 1,52$ & $39,00 \pm 2,64$ & $39,33 \pm 2,30$ & $31,00 \pm 4,35$ & 0,00 \\
\hline FIII & $40,66 \pm 2,08$ & $32,66 \pm 0,57$ & $38,66 \pm 1,52$ & $34,00 \pm 0,00$ & $38,66 \pm 0,57$ & $34,33 \pm 2,08$ & $33,66 \pm 0,57$ & $28,00 \pm 1,00$ & 0,00 \\
\hline $\begin{array}{c}\mathrm{p} \\
\text { (Kruskal } \\
\text { Wallis) }\end{array}$ & 0 & 0,11 & 0,05 & 0,05 & 0,03 & 0,03 & 0,08 & 0,40 & \\
\hline
\end{tabular}

After being treated for 4 weeks, the skin of the volunteers underwent a change in the category of being smooth (0-31). Data on changes in facial skin smoothness before and after the use of clay mask fineness (evenness) as seen in Table 2. The results of the facial evenness also can be seen in figure 1 and 2.

Figure 1. Photograph result of evenness and pore before treatment in week 1 


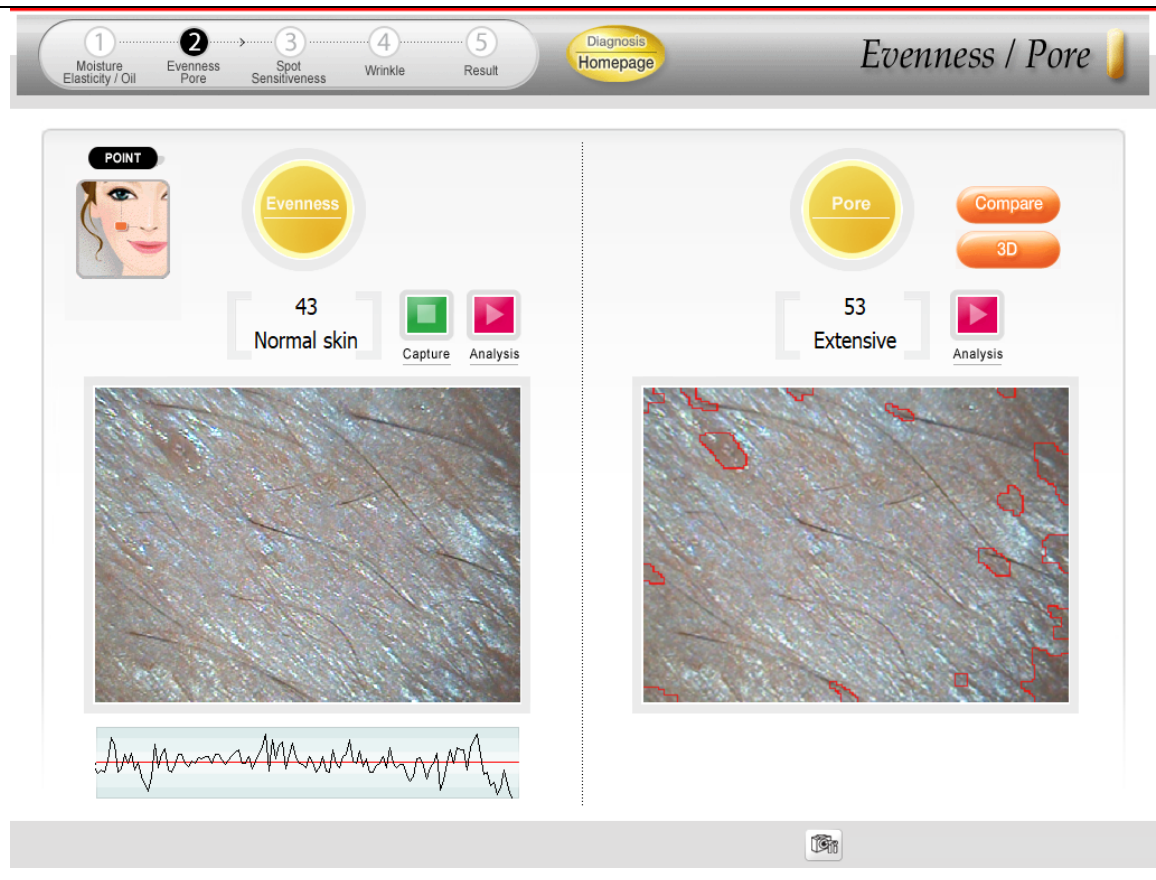

Figure 2. Photograph result of evenness and pore after treatment in week 4

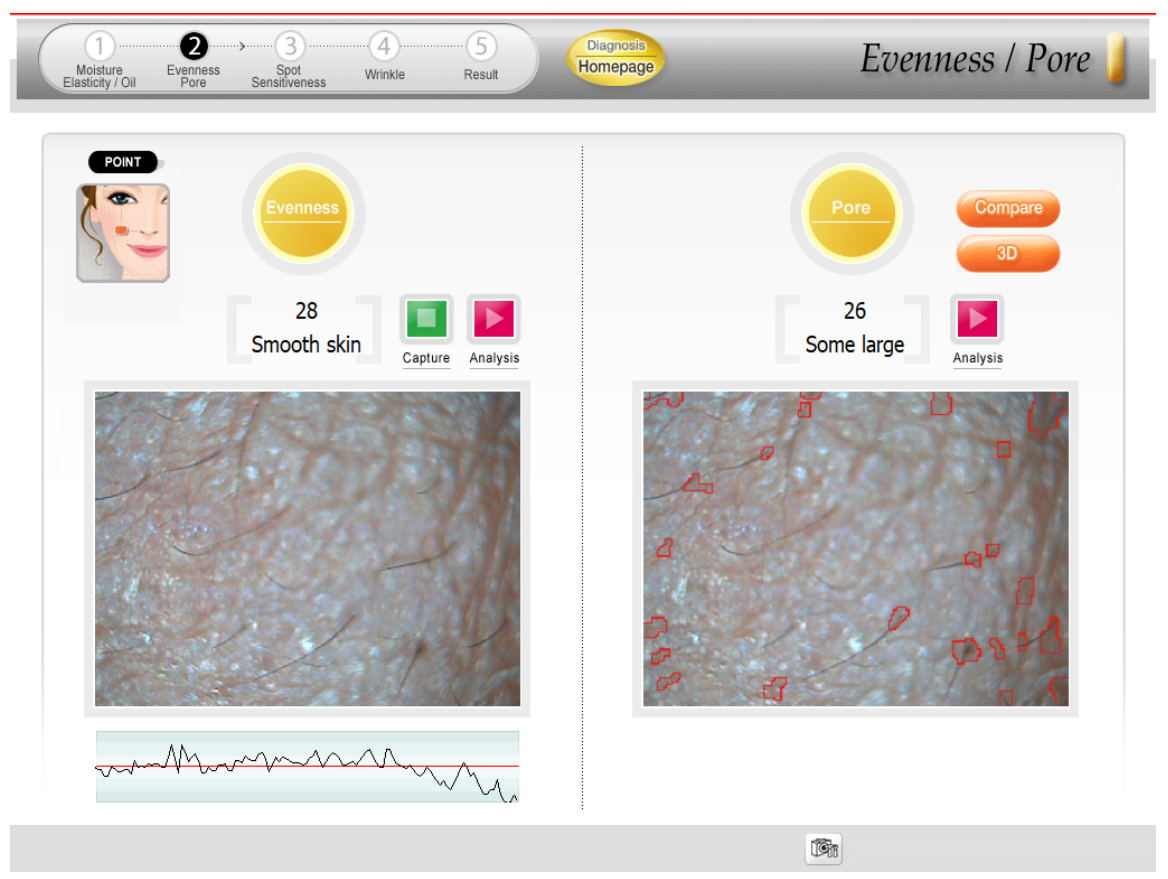

Table 3. Result of pore (Mean \pm SD) in research subject 


\begin{tabular}{|c|c|c|c|c|c|c|c|c|c|}
\hline \multirow[b]{2}{*}{ Formula } & \multicolumn{2}{|c|}{ Week 1} & \multicolumn{2}{|c|}{ Week 2} & \multicolumn{2}{|c|}{ "Week 3} & \multicolumn{2}{|c|}{ "Week 4} & \multirow{2}{*}{$\begin{array}{c}\mathrm{P} \\
\text { (Friedman) }\end{array}$} \\
\hline & Before & After & Before & After & Before & After & Before & After & \\
\hline F0 & $44,00 \pm 5,19$ & $40,00 \pm 5,00$ & $38,00 \pm 6,55$ & $33,33 \pm 7,23$ & $34,66 \pm 5,77$ & $30,66 \pm 7,02$ & $31,66 \pm 4,93$ & $29,33 \pm 3,21$ & 0,00 \\
\hline FI & $48,00 \pm 10,81$ & $39,00 \pm 9,16$ & $43,33 \pm 3,51$ & $37,00 \pm 3,00$ & $40,66 \pm 4,04$ & $35,66 \pm 2,88$ & $37,33 \pm 1,52$ & $30,33 \pm 6,02$ & 0,05 \\
\hline FII & $50,00 \pm 4,35$ & $41,67 \pm 2,88$ & $43,66 \pm 2,08$ & $33,33 \pm 1,52$ & $37,00 \pm 3,60$ & $34,00 \pm 2,64$ & $33,66 \pm 0,57$ & $25,33 \pm 4,04$ & 0,00 \\
\hline FIII & $50,00 \pm 3,60$ & $40,33 \pm 2,08$ & $40,66 \pm 4,04$ & $34,66 \pm 1,15$ & $34,66 \pm 0,57$ & $31,00 \pm 3,00$ & $29,33 \pm 1,52$ & $25,00 \pm 3,60$ & 0,00 \\
\hline $\begin{array}{c}\mathrm{p} \\
\text { (Kruskal } \\
\text { Wallis) }\end{array}$ & 0,57 & 0,98 & 0,47 & 0,40 & 0,25 & 0,35 & 0,05 & 0,32 & \\
\hline
\end{tabular}

Before treatment, the size of the pores of the skin of the volunteers is in the very large category (40-100). After being treated for 4 weeks, the skin of the volunteers underwent a change in the category of pores into several large (20-39). Data on facial skin pore changes before and after wearing clay masks as seen in table 3 .

Table 4. Result of spot (Mean \pm SD) in research subject

Prior to treatment, many stains on the skin of volunteers are in the category of very many stains

\begin{tabular}{|c|c|c|c|c|c|c|c|c|c|}
\hline \multirow[b]{2}{*}{ Formula } & \multicolumn{2}{|c|}{ Week 1} & \multicolumn{2}{|c|}{ Week 2} & \multicolumn{2}{|c|}{ Week 3} & \multicolumn{2}{|c|}{ Week 4} & \multirow{2}{*}{$\begin{array}{c}\mathrm{p} \\
\text { (Friedman) }\end{array}$} \\
\hline & SB & ST & SB & ST & SB & ST & SB & ST & \\
\hline F0 & $46,00 \pm 5,29$ & $42,33 \pm 7,57$ & $42,66 \pm 4,72$ & $38,00 \pm 4,35$ & $38,00 \pm 3,60$ & $35,66 \pm 4,04$ & $32,00 \pm 0,00$ & $28,33 \pm 0,57$ & 0,00 \\
\hline FI & $51,00 \pm 6,55$ & $43,00 \pm 3,00$ & $42,66 \pm 3,51$ & $36,33 \pm 3,21$ & $39,33 \pm 3,78$ & $35,00 \pm 2,64$ & $34,33 \pm 2,88$ & $27,66 \pm 3,51$ & 0,00 \\
\hline FII & $47,33 \pm 3,21$ & $39,66 \pm 4,16$ & $42,33 \pm 3,78$ & $35,33 \pm 3,78$ & $34,00 \pm 5,19$ & $28,66 \pm 4,93$ & $29,00 \pm 3,60$ & $26,00 \pm 7,54$ & 0,00 \\
\hline FIII & $52,33 \pm 9,29$ & $40,66 \pm 9,07$ & $45,00 \pm 4,58$ & $35,00 \pm 2,00$ & $36,00 \pm 3,46$ & $30,33 \pm 4,61$ & $27,66 \pm 0,57$ & $22,33 \pm 2,08$ & 0,00 \\
\hline $\begin{array}{c}\mathrm{p} \\
\text { (Kruskal } \\
\text { Wallis) }\end{array}$ & 0,65 & 0,88 & 0,72 & 0,81 & 0,57 & 0,15 & 0,07 & 0,24 & \\
\hline
\end{tabular}

(40-100). After 4 weeks of treatment, there is a change in the category of stains (20-39). Data on changes in facial skin blemishes before and after wearing clay masks can be seen in Table 4. 
Table 5. Result of wrinkle (Mean \pm SD) in research subject

The measurement of wrinkles on the volunteers' facial skin was carried out using a skin analyzer

\begin{tabular}{|c|c|c|c|c|c|c|c|c|c|}
\hline \multirow[b]{3}{*}{ Formula } & \multicolumn{8}{|c|}{ Mean \pm SD } & \multirow{3}{*}{$\begin{array}{c}\mathrm{p} \\
\text { (Friedman) }\end{array}$} \\
\hline & \multicolumn{2}{|c|}{ Week 1} & \multicolumn{2}{|c|}{ Week 2} & \multicolumn{2}{|c|}{ Week 3} & \multicolumn{2}{|c|}{ Week 4} & \\
\hline & SB & ST & SB & ST & SB & ST & SB & ST & \\
\hline F0 & $27,00 \pm 10,58$ & $24,33 \pm 13,31$ & $25,00 \pm 13,11$ & $22,66 \pm 14,84$ & $23,66 \pm 13,86$ & $17,33 \pm 6,02$ & $16,33 \pm 7,094$ & $14,00 \pm 7,93$ & 0,01 \\
\hline FI & $45,66 \pm 2,08$ & $39,00 \pm 0,00$ & $41,33 \pm 2,51$ & $32,33 \pm 6,50$ & $30,33 \pm 8,8$ & $23,66 \pm 5,03$ & $23,33 \pm 6,42$ & $17,33 \pm 7,57$ & 0,00 \\
\hline FII & $41,33 \pm 4,04$ & $32,33 \pm 5,77$ & $29,66 \pm 9,01$ & $25,00 \pm 5,29$ & $22,66 \pm 3,21$ & $19,00 \pm 2,64$ & $15,66 \pm 2,08$ & $11,33 \pm 1,15$ & 0,00 \\
\hline FIII & $48,00 \pm 1,73$ & $39,66 \pm 1,15$ & $41,33 \pm 4,04$ & $27,33 \pm 2,08$ & $27,66 \pm 0,57$ & $23,33 \pm 1,52$ & $19,00 \pm 3,60$ & $11,66 \pm 0,57$ & 0,00 \\
\hline $\begin{array}{c}\mathrm{p} \\
\text { (Kruskal } \\
\text { Wallis) }\end{array}$ & 0,03 & 0,11 & 0,09 & 0,58 & 0,39 & 0,21 & 0,26 & 0,33 & \\
\hline
\end{tabular}

with 10 times the magnification lens and the color of the sensor light blue. Data on changes in facial skin wrinkles before and after wearing clay masks can be seen in Table 5 .

\section{Discussion}

The ethanol extract of grapes contains chemical compounds in the form of glycosides, tannins, flavonoids, triterpenoid / steroid saponins and alkaloids. The extraction process produces the same substances as the substances contained in the simplicia.

Measurements were made by measuring the condition of the volunteers' skin in order to see the great anti-aging effect obtained after treatment with clay mask ethanol extract to dispose of grapes. Based on the normality test with the Shapiro-Wilk Test, $\mathrm{p}$ values $<0.05$ were obtained so that the data concluded were not normally distributed, so it continued. with the Kruskal Wallis test then continued with the Mann-Whitney Test and Wilcoxon Test.

For physiological functions, the skin needs fat and water. The layer of fat on the surface of the skin and the materials in the stratum corneum which are hygroscopic that can absorb water and are in a functional relationship called the Natural Moisturizing Factor. The ability of the stratum corneum to bind water is very important for the flexibility and flexibility of the skin [16].

Dry skin is caused due to lack of oil production from the sebaceous glands (oils) which tends to result in premature aging and wrinkle prone [17]. Meanwhile, according to Sari and Setyowati (2014) "dry skin is skin with a low or low water content". So that dry skin needs to be treated properly so it does not look dull [18]. 
Enlarged skin pores also one of the signs of premature aging. This can happen because increasing age and excessive sun exposure cause dead skin cells to accumulate and reduce skin elasticity, making skin pores appear enlarged [19].

Antioxidants in cosmetic ingredients function to moisturize the skin [20]. The antioxidants in clay masks were derived from grapes, namely flavonoids and tannins. Flavonoids are able to stimulate the formation and production of skin collagen. Collagen serves to increase the elasticity and strength of the skin, so that the pore size can could be reduced $[21,22]$

The most important cause of black spots is due to prolonged sun exposure so that it causes serious damage to the skin such as burning, redness and brown spots on the skin. The amount of sunlight that is exposed to the skin results in the formation of increasingly active melanin. Melanin functions in the determination skin color [23].

The tyrosinase enzyme has an important role in the formation of melanin. Flavonoids are useful for reducing melanin formation by directly inhibiting tyrosinase activity in the process of melanogenesis [24].

Exposure to sunlight that emits ultraviolet radiation (UV) can trigger photoaging with the appearance of wrinkles and blemishes on the face. Wrinkles arise due to decreased collagen production and abnormal elastin accumulation [25]. In another study, "The Effect of Extract Broccoli on Skin Photoaging" was also successful in preventing Ultraviolet - B (UVB) induced by Matrix Metalloproteinase (MMP-1) expression at both Messenger Ribonucleic Acid (mRNA) and protein levels [26].

The role of collagen is to maintain the structure of the skin. Elastin plays a role in skin elasticity in the body so that the skin has the ability to stretch and relax [27]. 
[1] Putro, D. S., 1997. Agar Awet Muda. Malang: Universitas Negeri Malang Press. Halaman $3,5,21-22$.

[2] Anggowarsito, J.L., 2014. Aspek Fisiologi Penuaan Kulit. Jurnal Widya Medika Surabaya Vol. 2 No.1.

[3] Wahyuningsih, K. A., 2011. Astaxanthin Memberikan Efek Proteksi Terhadap Photoaging. Damianus Journal of Medicine, Volume 10, pp. 149 - 160.

[4] Fadiyah, A.F., Wardhani, R.M., Rahmatika, N. \& Wijayanti, S.P.M., 2018. Eksplorasi Potensi Ekstrak Cair Daun Kecombrang yang Mengandung Antioksidan Sebagai Penetralisir Radikal Bebas dalam Darah Petugas SPBU. Universitas Jenderal Soedirman.

[5] Inggrid, H. M. dan Herry, S., Ekstraksi Antioksidan dan Senyawa Aktif dari Buah Kiwi (Actinidia deliciosa). Lembaga Penelitian dan Pengabdian kepada Masyarakat Universitas Katolik Parahyangan 2014.1.

[6] Sinly., 2008. Antioksidan Alami Di Sekitar Kita (Online). http://www.chem-is try.org/artikel_kimia/kimia_pangan/antioksidan-alami-di-sekitar-kita.com (Diakses tanggal 08 Oktober 2012).

[7] Lobo, V., Patil, A., Phatak, A., \& Chandra, N. (2010). Free radicals, antioxidants and functional foods: Impact on human health. Pharmacognosy reviews, 4(8), 118-126. https://doi.org/10.4103/0973-7847.70902

[8] Dewi, R., Effionora,A. dan Yunita., 2014. Uji Stabilitas Fisik Formula Krim yang Mengandung Ekstrak Kacang Kedelai (Glycine max). Pharm Sci Res ISSN 2407-2354, Volume 1 No.3.

[9] Haerani, A., Anis,Y.C. dan Anas, S., 2018. Antioksidan Untuk Kulit. Farmaka, Volume 16 No.2.

[10] Anindita, A.H \& Masluhiya, S. 2017. Formulasi Masker Alami Berbahan Dasar RumputLaut dan Cokelat Mengurangi Keriput dan Bintik Noda Pada Kulit Wajah. Jurnal Care, Volume 5.

[11] Yang, J., Martinson, T. E., \& Liu, R. H. (2009). Phytochemical profiles and antioxidant activities of wine grapes. Food Chemistry, 116(1), 332-339.

[12] Unusan, N. (2020). Proanthocyanidins in grape seeds: An updated review of their health benefits and potential uses in the food industry. Journal of Functional Foods, 67, 103861.

[13] Li, H., Xiaoyu, W., Peihong, L., dan Yong, L., 2008. Comparative Study of Antioxidant Activity of Grape (Vitis vinifera) Seed Powder Assessed by Different Methods. Journal of Food and Drug Analysis, Vol. 16, No. 6.

[14] Mustanti, L.F., Formulasi Sediaan Masker Clay Ekstrak Ubi Jalar Ungu (Ipomoea batatas (L.) Lam) dan Uji Efek Anti-Aging. Program Studi Sarjana Farmasi Fakultas Farmasi Universitas Sumatera Utara 2018.

[15] Toscano, L. T., Tavares, R. L., Toscano, L. T., Silva, C. S. O. D., Almeida, A. E. M. D., Biasoto, A. C. T., ... \& Silva, A. S., 2015. Potential ergogenic activity of grape juice in runners. Applied Physiology, Nutrition, and Metabolism, 40(9), 899-906.

[16] Tranggono, R.I., \& Latifah, F. 2007. Buku Pegangan Ilmu Pengetahuan Kosmetik. Jakarta: PT Gramedia Pustaka Utama. Halaman 29-31, 107.

[17] Hanzola, G. F., Rahmiati, R., \& Astuti, M., 2015. Pengaruh Penggunaan Masker Lidah Buaya Terhadap Perawatan Kulit Wajah Kering. E-Journal Home Economic and Tourism, $8(1)$.

[18] Sari, N. R., \& Setyowati, E., 2015. Pengaruh Masker Jagung dan Minyak Zaitun Terhadap Perawatan Kulit Wajah (Doctoral dissertation, UNIVERSITAS NEGERI SEMARANG).

[19] Bogadenta, A., 2012. Antisipasi Gejala Penuaan Dini dengan Kesaktian Ramuan Herbal. Yogyakarta: Buku Biru. Halaman 16-17.

[20] Fauzi, A. R., 2013. Merawat kulit dan Wajah. Elex Media Komputindo.

[21] Achroni, K., 2012. Semua Rahasia Kulit Cantik dan Sehat Ada Disini. Yogyakarta: Javalitera. Hal. 13 - 17. 
[22] Khan, H.M.S., Akhtar, N., Rasool,F., Khan, B.A., Mahmood, T., \& Khan, M. S., 2010. In Vivo Evaluaton of Stable Cream Containing Flavonoids on Hydration and TEWL of Human Skin. International Journal of Pharmacological and Pharmaceutical Sciences. 4(11): 22-25.

[23] Susana, T., 2011. Pemberian Ekstrak Air Ubi Jalar Ungu (Ipomoea batatas) Menghambat Penuaan Dini Kult dengan Menghambat Peningkatan Kadar MMP-1 pada Tikus yang Dipajan Sinar UVB. Tesis. Denpasar: Universtas Udayana.

[24] Charissa, M., Djajadisastra, J., \& Elya, B., 2016. Uji Aktivitas Antioksidan dan Penghambatan serta Uji Manfaat Gel Ekstrak Kulit Batang Taya (Naucla subdita) terhadap Kulit. Jurnal Kefarmasian Indonesia. 6(2): 98-106.

[25] Medica., 2011. Mengenal Kulit dan Penuaan Dini. http://medicastore. com/ ser- c/penuaan_dini.htm .Diakses tanggal 24 November 2019.

[26] Effect of Broccoli Flower Extract (Brassica oleracea L. var italica Plenck) on Inhibition of Photoaging Viewed from Matrix Metalloproteinase-1 Expression in Human Skin Fi- broblast. In; Journal of Biology Agriculture and Healthcare ISSN 2224-3208, Vol. 4 No. 26, pp. 54-9. 2014 https://doi.org/10.7176/JBAH

[27] Pawlaczyk, M., Lelonkiewicz, M., \& Wieczorowski, M., 2013. Age-dependent biomechanical properties of the skin. Postepy dermatologii $i$ alergologii, 30(5), 302-306. https://doi.org/10.5114/pdia.2013.38359 